\title{
PERCEPTIONS OF HEALTH ASSESSMENT, TREATMENT AND CARE BY COMMUNITY NURSES
}

SS Monamodi

Master's Student

Department of Nursing Science, Rand Afrikaans University

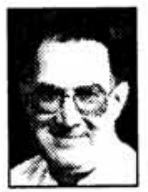

SD Roos

D Cur, Senior Lecturer

Department of Nursing Science, Rand Afrikaans University

\section{ABSTRACT}

The aim of this study was to explore and describe whether primary health care nurses are equipped with the skills they require in health assessment, treatment and care. An exploratory, descriptive and contextual design was employed. The data was obtained through focus group interviews with community nurses in the first phase and with patients in the second phase of data collection respectively. In the third phase, guidelines were compiled from the data obtained in phases one and two to outline how primary health care nurses should function in the health assessment, treatment and care of their patients. The results of this research show that community nurses and patients perceive primary health care nurses to be skilful in psychomotor, cognitive and affective aspects. It also became clear that there are factors in the primary health care setting that can affect the desired skills of primary health care nurses negatively. The most important of these are overcrowded facilities, shortage of human and material resources, for example drugs and lack of legal coverage. Lack of in-service education of nurses who trained some years ago, was also one of the factors that affected their skills. It is recommended that the guidelines be implemented and that the relevant shortcomings be rectified.

\section{OPSOMMING}

Die doel van hierdie navorsing was om te verken en te beskryf of die primêre gesondheidsorgverpleegkundiges met die nodige vaardighede toegerus is, ten einde in staat te wees om kwaliteit pasiëntsorg deur gesondheidsberaming, behandeling en verpleegsorg, te verleen. ' $n$ Verkennende, beskrywende en kontekstuele ontwerp is deur die navorser gebruik om bogenoemde vraag te beantwoord. Tydens die eerste fase is data versamel deur middel van fokusgroeponderhoude met gemeenskapsverpleegkundiges, en tydens die tweede fase met pasiënte. Die navorsing is onderneem om die persepsies van gemeenskapsverpleegkundiges en pasiënte ten opsigte van gesondheidsberaming, -behandeling en sorgvaardighede te verken en te beskryf. Die resultate van hierdie navorsing toon dat die gemeenskapsverpleegkundiges en pasiënte waarneem dat primêre gesondheidsorgverpleegkundiges vaardig is in psigomotoriese, kognitiewe en houdingsaspekte. Tog het dit ook duidelik getoon dat daar faktore in die primêre gesondheidsorgopset is wat die vaardighede van die primêre gesondheidsorgverpleegkundiges negatief kan beïnvloed. Die belangrikste hiervan is oorvol fasiliteite, tekort aan menslike en materiële hulpbronne soos medikasie en ' $n$ gebrek aan wetlike beskerming. ' $n$ Gebrek aan indiensopleiding van verpleegkundiges wat ' $n$ aantal jare gelede opgelei is, was ook een van die faktore wat vaardighede beïnloed het. Daar word aanbeveel dat die riglyne geïplementeer word en dat die relevante tekortkominge aangespreek word.

\section{INTRODUCTION}

Maldistribution of health facilities and resources as well as a tendency of doctors and nurses to specialise and emigrate, place a greater responsibility on the remaining health manpower. The shortage of doctors, especially in rural areas led to the extension of the scope of practice of registered nurses by the South African Nursing Council. The Nursing Act 1978 (Act No. 50 of 1978) was amended by addition of Section $38 \mathrm{~A}$ in 1981. This section allowed registered nurses to perform physical examinations, diagnose and prescribe treatment in accordance with protocols, in the absence of a medical practitioner and to dispense medicine in the absence of a pharmacist. To equip community nurses with skills to carry out these functions competently, the South African Nursing Council introduced the post-basic Diploma in Clinical Nursing Science, Health Assessment, Treatment and Care in 1982 (SANC, 1982).
The White Paper on Transformation of Health Systems in South Africa (1997) explains that the abilities (knowledge, skills and attitudes) of all health personnel should be used optimally to ensure quality care in the health facilities (Department of Health, 1997:54). This has led to the introduction of a national framework for the training and development of health personnel and primary health care nurses who will, as the core frontline professionals, be exposed to continual professional development and evaluation.

Patients have become used to the fact that a medical practitioner performs a physical examination during consultation in the clinic. When primary health care nurses started performing physical examinations, the community viewed it with scepticism, as they did not want to be examined by nurses. Extending the role of community nurses to perform functions initially performed by doctors and pharmacists raised a lot of emotions and differences of opinions by various role-players 
Patients are beginning to be more informed about their rights and community nurses are being questioned for malpractice. Health care professionals, for professional and ethical reasons, realise that they need to have a method of defining and showing that they are providing quality services. The primary health care nurse is responsible for the rendering of a comprehensive primary health care service. They need to be competent (knowledgeable and skilled) to diagnose and treat the patient appropriately. This includes emergency services when necessary.

The following research question is applicable: "What are the perceptions of the community regarding the skills of community nurses in health assessment, treatment and care in selected primary health care clinics in North West Province?"

Due to these problems related to the extended role of the primary health care nurse, the researcher embarked on the study to attain the following objectives:

- To explore and describe the perceptions of the community nurses regarding their skills in health assessment, treatment and care in selected primary health care clinics in the North West Province.

- To explore and describe the perceptions of the patients regarding the health assessment, treatment and care they receive from the community nurse.

- To write guidelines on how the community nurse should function in the health assessment, treatment and care of her patients.

\section{TERMINOLOGY}

\section{Primary Health Care}

According to the World Health Organisation, primary health care is essential health care made universally accessible to individuals and families in communities by means acceptable to them, with their full participation and at a cost that the community and the country can afford to maintain at every stage of development, in the spirit of self-reliance and selfdetermination. It forms an integral part of the country's health system, of which it is the central function and main focus of the overall social and economic development of the community. It is the first level of contact of individuals, the family and the community with the National Health System in bringing health care as close as possible to where people live and work, and constitutes the first element of a continuing health care process (World Health Organisation, 1982:3).

\section{Community Nurse}

The community nurse is registered with the South African Nursing Council, as a general and community nurse and is as responsible for comprehensive primary health care.

\section{Perceptions}

To become aware or get to understand how human sensory systems become aware in a conceptual or epistemological approach. What is known is a product of sensory encounter with objects and events (Collins Encyclopedia, 1991:148).

\section{Primary Health Care Nurse}

The nurse who is registered with the South African Nursing Council in Health Assessment, Treatment and Care, who is conditionally authorised to perform selected functions of a medical practitioner.

\section{Diploma in Clinical Nursing Science, Health Assessment, Treatment and Care}

A diploma course which leads to the registration of a qualification with the South African Nursing Council, in which clinical skills, diagnosis of pathology and prescription of medicine and primary health care management skills are taught by primary health care nurse trainers (Vlok, 1992:200)

\section{Health Assessment, Treatment and Care Course}

A post basic course listed by the South African Nursing Council, to empower the nurse in health assessment, treatment and care.

\section{Skill}

The psychomotor, cognitive and affective skills related to health assessment, treatment and care.

\section{RESEARCH DESIGN AND METHOD}

An exploratory, descriptive and contextual study was undertaken, exploring and describing the perceptions of patients and community nurses in so far as the skills in health assessment, treatment and care are concerned. A specific area in the North West Province and a particular category of nurses and patients were used. The health care services in the North West Province serve a population of 3506770 people and occupies an area of 118710 square kilometres (Department of Health North West Province, 1995:(6):2)

The ratio of resources in the health care services is as follows: medical practitioners per 10000 population: 2 ; nurses per 10000 population: 27 (Voice of Primary Health Care, 1995:2). Added to the overload on health care workers, there is also the problem of maldistribution of human resources in the North West Province and a strong bias towards hospital based care in the Province. $57 \%$ of the primary health care facilities in the Province offers comprehensive mother and child health care services. Klerksdorp region offers the least while Taung district offers $94 \%$ comprehensive health care services (Department of Health, 1996b:77). There are thirtysix clinics in the Mafikeng district where the research was conducted and three clinics were used to conduct the study. The district consists of $80 \%$ rural area and $20 \%$ urban area.

In the clinics registered nurses who are in possession of the post basic qualification in Clinical Nursing Science, Health Assessment, Treatment and Care perform physical examinations and diagnose and prescribe treatment for the patients who visit the clinics with various ailments. They only refer patients with health problems that fall outside their scope of practice. Although the distribution of professional nurses in possession of the Clinical Nursing Science, Health 
Assessment, Treatment and Care qualification ranges from one, two and three per clinic, the average is one per clinic. The aim of the Department of Health and Developmental Social Welfare is to have all comprehensive health care services manned by nurses qualified in health assessment, treatment and care. This is in line with the aim of the National Health System that there must be a programme of retraining of all existing health care workers and re-orientating them to the primary health care approach. The aim was to train $25 \%$ of district personnel by the end of 1995 and $50 \%$ by the end of 1997 (Voice of Primary Health Care, 1996:50).

Focus group interviews were conducted with the community nurses and patients, to collect data on their perceptions. Focus group interviews were conducted in accordance with the principles described by Burns and Grove (1995:104). These focus groups were transcribed, followed by a content analysis and described by Tesch (in Cresswell, 1994:155).

The study was conducted in three phases. In the first phase a purposive sample of community nurses qualified in health assessment, treatment and care who were working in both fixed and mobıle clinics in the particular district, was used. In the second phase a convenient sample of patients who visited the clinic on the day of the focus group interviews, and who had been examined by the nurse qualified in health assessment, treatment and care, was used. In phase three the data gathered from the literature study phase one and two of the study was utilised to describe guidelines on how the primary health care nurse should function in a primary health care setting in order to render quality patient care.

The target population in the first phase consisted of primary health care nurses who are qualified in the course in Health Assessment, Treatment and Care. They had to be employed for not less than a year after completion of the course in health assessment, treatment and care. They had to be employed in a mobile or fixed clinic at the time of the interview. Five primary health care nurses were used for the focus group interviews.

The target population in the second phase consisted of five patients in each of the three clinics that were used for the focus group interviews. A primary health care nurse daily in the clinic examines an average of hundred patients. The sample was chosen conveniently after the primary health care nurses had examined them. The patients had to be conversant either in Setswana, Afrikaans, English or Xhosa. They had to meet the following criteria:

- Adults of different genders between the ages of 19 and 65 years.

- Patients who were not seriously ill and who were in a stable physical and mental condition.

The central question to the primary health care nurses was: "What are your perceptions of the skills of community nurses in health assessment, treatment and care?" To the patients the same central question was: "Maitemogelo a gago a ntse jang ka bokgosi ba baoki ba ba thathobang balwetsi?"
Trustworthiness was ensured through the principles described by Guba and Lincoln (1992:324):

- Prolonged engagement by the researcher as a primary health care nurse practitioner for more than ten years and involved in the education of Health Assessment, Treatment and Care;

- the tape recorded focus group interviews were transcribed verbatim;

- an external independent coder, with a masters degree in Public Health and involved in the education of Health Assessment, Treatment and Care was used;

- triangulation by means of data resources (collection of data from primary health care and patients) followed by a literature control;

- dense description of the research process.

\section{RESULTS}

The results are classified into psychomotor, cognitive and affective skills of primary health care nurses. The logistics involved in, and the accessibility of primary health care services to patients were also recorded.

\section{Psychomotor skills of primary health care nurses}

From the results of the focus group interviews it is concluded that primary health care nurses improved the quality of care they gave their patients through their psychomotor skills in health assessment, treatment and care. They were found to possess communication skills that made them good listeners during history taking thus encouraging a trusting relationship between the patient and the nurse. They examine the patients with confidence and possess the skills to examine the patients effectively and thoroughly and to write their records properly. Protocols on the Essential Drug List are used successfully by the primary health care nurses to manage patients with different health problems. Primary health care nurses and patients expressed their concern that most drugs on the Essential Drug List were always out of stock.

Bierman (1992:134) found in her research that community nurses develop more confidence after being trained in Health Assessment, Treatment and Care and that they have the courage to stand by their convictions.

Knight and Buppert (1995:45) revealed that primary health care nurses are $20 \%$ less costly than medical practitioners in their care. This cost-effectiveness resulted from skills developed by community nurses during the Health Assessment, Treatment and Care Course (Voice of Primary Health Care, 1993:31).

This was confirmed by Truscott (1990:43) when he gave his view of a trained primary health care nurse: "She is a highly trained and sophisticated specialist in the clinical diagnosis and management of patients. She is a facilitator, co-ordinator of health care facilities, first contact person, communicator, primary preventer and initiator of individual, family 
and community preventative, promotive and curative health care".

\section{Cognitive skills of primary health care nurses}

Working with the multi-disciplinary team increases the knowledge of primary health care nurses through discussions and feedback from referrals to other team members. The knowledge of primary health care nurses increases through teaching and acting as mentors for nurses from universities, technikons and colleges of nursing, who visit clinics for practical experience. They pass knowledge on to patients and their relatives through health education on promotive and preventive aspects of disease such as preparation of oral hydration solution. They also agreed that their knowledge becomes outdated with improved technology and the introduction of new drugs on the Essential Drug List.

Brown and Olshansky (1997:47) stated that primary health care nurse practitioners eventually made significant advances in becoming less anxious and more settled during health assessment, treatment and care of their patients. They showed the three sub-categories of meeting challenges namely increasing competence, gaining confidence and acknowledging system problems. From this stage onwards they became more skilful in managing patients and procedures.

\section{Affective skills of primary health care nurses}

Patients perceived that primary health care nurses provided a relaxed atmosphere during physical examination of patients, because they talk to patients in their own language and explained the procedure to the patient before starting on the physical examination.

They:

- not only consider the physical aspects of the patient but also the psychological and social aspects;

- use non-drug management of patients with psychosocial disorders and provide health education;

- counsel patients and use stress relieving skills like exercises and relaxation; and

- were more likely to ask family history and give an impression that they are not only interested in the problem that brought the patient into the clinic, but in the whole family.

Knight and Buppert (1996:44) confirmed the above statements by stating that nurses are more likely to ask about the patient's diet and psychological history, thereafter counselling and giving stress relieving exercises to help the patient deal with stress. They are better listeners because of their background of basic training in developing a caring attitude. This also helps them to communicate effectively with patients, community and clinic committees, health organisations, patients' relatives and the rest of the community and the multi-disciplinary team.

According to the Voice of Primary Health Care (1995:9), primary health care nurses are more likely to do counselling when managing patients with psychosocial disorders like peptic ulcers. This was associated with the caring attitude that these nurses gain during their basic training, which helps them to manage psychosocial disorders even though they are nurse practitioners.

\section{The influence of logistics on the skills of prima- ry health care nurses}

Primary health care nurses expressed dissatisfaction that they were not legally covered. Protocols were not updated. They were not authorised to either prescribe or dispense drugs due to the new dispensation and the formulation of the new acts, rules and regulations. Although they expressed the wish to render a comprehensive health service, they were forced by lack of security to close at 16:30. There were either no security guards or they were elderly and unarmed. Clinic premises had no security fences. Clinics were so small that there was no space to maintain privacy for physical examination. There was no space to counsel patients with psychosocial problems. This caused patients to withhold history that might be important for correct diagnosis. Overcrowding of patients at the clinics was found to affect the skills of primary health care nurses negatively and the following causes were found to contribute:

- Patients were advised to start consulting at their local clinics first before being referred to hospitals.

- There is shortage of primary health care trained nurses and nurses taking severance packages aggravate the problem.

- Patients were concerned about the absence of doctors at clinics, and felt that patients may die in an emergency being transferred to the faraway hospitals.

- Drugs were consistently out of stock, this led to patients not being properly treated and losing confidence in the primary health care nurses. This could also lead to high mortality and morbidity rate.

- Primary health care nurses left patients unattended when they went for lunch and tea breaks. Nurses perceived this to be due to shortage of staff.

The view of the South African Nursing Council is that, in the absence of a medical practitioner, the person most suitable to do the work is the primary health care nurse (SANC, 1982:3). This also confirms the World Health Organisation's principle, which was highlighted at the Alma Ata Conference, namely that primary health care nurse services should be made accessible by all means to the people in the community (World Health Organisation, 1985:7).

Mekwa, Uys and Vermaak (1992:8) mentioned a lack of commitment to patient care amongst registered nurses. These researchers mentioned a few factors that caused such lack of commitment, namely management flaws, past experiences, cultural factors, poor socialisation of student nurses, job dissatisfaction and "passing the buck." 


\section{Accessibility of primary health care services to patients}

Patients perceived that primary health care nurses provided an essential service because they rendered a comprehensive service where there is no doctor. Patients no longer travelled long distances just to consult a doctor for minor ailments. They said they made savings in terms of time and money. Although the above benefit to the patients created overcrowding at clinics, primary health care nurses were of the view that overcrowding was due to a shortage of staff.

\section{GUIDELINES}

The guidelines focus on psychomotor, cognitive and affective skills, as well as certain logistics in a primary health care clinic. These guidelines are based on the results of data obtained from interviews and literature used.

\section{Psychomotor skills of primary health care nurses}

\section{History taking}

Primary health care nurses should possess:

- Proper history taking skills, taking into consideration building of rapport and communication, so that the patient will trust the nurse and divulge the correct information that will lead to the correct diagnosis.

- An emotional relationship between the nurse and the patient should be build.

- Accurate information should be obtained.

- The illness should be explained to the patient.

- Support should be provided to the patient.

- The primary health care nurse should keep in mind that patients react differently to illness, depending on age, gender, personality, cultural, social and economic circumstances (Turner, 1992:12).

\section{Physical examination}

Physical examination should be done with consideration of the patients' physical and mental condition and principles for proper physical examination should be adhered to. General assessment should be done on hydration, gait, movements, jaundice, anaemia, cyanosis, clubbing, oedema and lymphadenopathy.

The head and neck should be examined including the scalp, face, eyes, ears and mouth. The chest should be inspected for movements, symmetry, pulsations, skin condition and malformaties. Palpate for symmetry of chest movements and apex beat. Percuss for resonance comparing both sides. Auscultate for air entry and adventitious sounds of the lung fields and for heart sounds. The abdomen should then be inspected for any distension, pulsations, skin changes and scars, auscultated for bowel sounds and palpated for masses or fluid and then percussed to verify. The musculo-skeletal, the nervous and the genito-urinary systems should then be examined.

\section{Prescription of treatment}

Knight and Buppert (1995:45) revealed that primary health care nurses are $20 \%$ less costly than medical practitioners in their care. This cost-effectiveness resulted from the skills developed by community nurses after training in Health Assessment, Treatment and Care and justified the expenses of extra saving on primary health care. One respondent stated: "I am no longer afraid of examining patients like before. One used to not be sure which drugs to order for which condition. Through this training I am able to treat the patient effectively".

The primary health care nurse should start with non-drug management and health education. Prescription of drugs should be according to the following principles:

- Adopting protocols on the Essential drug List should ensure rational use of drugs.

- Far from being restrictive the Essential Drug List should be seen as enabling and facilitating.

- It empowers and builds capacity at the primary health level.

It is a major avenue towards the attainment of equity in health care delivery and the quality of care.

\section{The cognitive skills of primary health care}

Primary health care nurses perceived that their knowledge increased through discussions with multi-disciplinary team members. Through feedback from referrals their knowledge of disease pathology and management of different disease conditions is increased. A respondent said: "Working with the multi-disciplinary team helped me to enter into a dialogue and to reflect critically and learn intentionally. This helped in my professional growth. I am convinced that experience is a prerequisite for expertise. Working together facilitates problem-solving and promotes accountability".

For the primary health care nurses who work alone in the most rural and remote areas where there are no doctors it is important to possess:

- Proper working knowledge of general disease conditions, clinical manifestations of diseases and different protocols on the Essential Drug List for proper management of disease. This knowledge must be applied successfully in the diagnosis and management of patients.

- Knowledge in clinical management must be applied for example, in safe keeping and ordering of drugs, control of human and material resources and the day to day running of the clinic.

- Acts, rules and regulations that control the clinic must be implemented by formulating policies and guidelines for the clinic.

\section{The affective skills of primary health care nurses}

The primary health care nurses need to ensure quality health care by using the following affective skills: 
- Senior primary health care nurses who are in management positions should ensure the patients' as well as the personnel's physical security.

- Psychological safety must be ensured through proper legal and ethical measures, for example, policy manuals, acts, rules and regulations that are in place and updated from time to time.

- Listening skills must be used to listen actively to what patients and relatives say and at the same time non-verbal communication must be observed.

- Empathy should be practised by always trying to understand what other people feel without expressing own judgement about what is right or wrong and helping the patient to make his own conclusions to solve his problems.

- Primary health care nurses should remain objective and help distressed patients to clarify and accept their situations. This will help them to work out their own solutions.

\section{Logistics in primary health care practice}

A safe environment should be created for the patients and staff at the clinics (South Africa, 1993) through the following measures:

Well-trained and armed security guards should be employed at the clinics. Security fences, barred doors and windows should be installed. Building of more clinics should be motivated, with enough space to prevent overcrowding and to ensure privacy during physical examinations. There should be a $100 \%$ supply of drugs to the clinics to ensure proper management of the different conditions that are managed by the primary health care nurses. Every clinic should be staffed with primary health care nurses who are trained in health assessment, treatment and care. From a situational analysis that was conducted in 1995, nine hundred nurses should be trained to overcome the shortage of clinically skilled nurses. More primary health care nurses should be trained to overcome attrition rate and retirement of other primary health care nurses. Primary health care nurses should receive in-service education on clinical skills, common diseases, the Essential Drug List and the use of modern technology such as computers. At least one doctor should be allocated at each clinic to examine patients who are referred by primary health care nurses and to resuscitate patients during emergencies.

All these guidelines are directed at assisting the primary health care nurses to deliver quality patient care by mobilising their resources to their full potential. A holistic approach is recommended so that primary health care nurses can integrate and internalise these perceptions in a positive manner. It is important that district and regional managers must support the primary health care nurses, by acknowledging the difficulties that they come across in the normal day to day duties, and assisting them in motivating the improvement of such a stressful environment.

The guidelines generated from this study can be considered in designing in-service education programmes and curricula for the training of primary health care nurses. The researcher believes that it would be worthwhile to undertake further studies in this field when the transition period is over and Health Acts, Nursing Acts and other relevant Acts have been implemented.

\section{CONCLUSION AND RECOMMENDATION}

A holistic approach is utilised by the nurses in the Health Assessment, Treatment and Care of patients although they do experience logistical difficulties in their normal day to day service rendering. It is recommended that the guidelines be implemented and that the shortcomings identified by the study be rectified in the new dispensation in health services.

\section{BIBLIOGRAPHY}

Bierman, JK 1992: Legal limitations in primary health care nursing practice. Johannesburg: RAU, pp. 133-134.

Brown, M \& Olshansky, E 1997: From limbo to legitimacy. A theoretical model fo the transition to the primary health care nurse practitioner role. Nursing Research, 46, Jan/Feb. 1997:48-51.

Burns, N \& Grove, SK 1993: The practice of nursing research, critique and utilization. London: WP Saunders.

Collins English Dictionary 1991. Great Britain: Collins Sons \& Co. Ltd.

Corey, M 1995: Voice of primary health care. Issue 1. WITS: Health Systems Trust, 12.

Creswell, JW 1994: Research design: qualitative and quantitative approaches. London: Sage.

Department of Health 1996: A policy document, restructuring the national health system for a universal primary health care. Pretoria: DOH, pp. 14, 43.

Department of Health 1996: National Health Bill. Pretoria: DOH, p. 28.

Department of Health 1997: White Paper on Transformation of the Health System in South Africa. No. 17910 (382) 16 April. Pretoria: DOH.

Department of Health 1995: A Policy Document for the Development of a District Health System. Pretoria: DOH, p. 18.

Guba, EG \& Lincoln, YS 1985: Naturalistic inquiry. London: Sage

Knight \& Buppert, JD 1995: Justifying nurse practitioners existence, hard facts to hard figures. Nurse Practitioner, August 1995:43-45. 
Mekwa, JM; Uys, LR \& Vermaak, MV 1992: Commitment to patient care: An exploratory study among registered nurses in Bophuthatswana. Curationis, 15(4), 1992:8-11.

South African Nursing Association 1994: Policy Statements. Pretoria: SANA.

South African Nursing Council 1978: Act No. 50 Section 30A, 45, 22. Pretoria: SANC.

South African Nursing Council 1984, 1995: Regulation 2598. Scope of Practice for Nurses. Pretoria: SANC.

South African Nursing Council 1982: Regulation 48. Regulation for Diploma in Clinical Nursing Science, Health Assessment. Treatment and Care. Pretoria: SANC.

South African Nursing Council 1982: Directive for the Diploma in Clinical Nursing Science, Health Assessment, Treatment and Care. Pretoria: SANC.

South Africa 1993: Occupational Health and Safety Act, 1993 (Act 181 of 1993).

South Africa 1997: The White Paper for the Transformation of the Health System in South Africa.

Truscott, A 1990: Urban primary health care. Nursing RSA,
5(11/12), 1990:43, 45.

Turner, D 1992: Physical Examination for primary clinical practitioner. Cape Town: King Edward Trust.

Van Vuren, M 1990: Primary health care rendered by nurses attached to mobile clinics in certain rural areas. Auckland Park: RAU (Unpublished dissertation).

Vlok, ME 1992: Manual of Community Nursing \& Psychiatry. Cape Town: Juta.

Voice of Primary Health Care 1993: Study on prescribing patterns of Primary Health Care and Clinic nurses. Johannesburg: Wits Health Systems Trust, pp. 25-31.

Voice of Primary Health Care 1995: Issue 1. Johannesburg: Wits Healths Systems Trust, p. 8.

Voice of Primary Health Care 1996: Issue 1. Johannesburg: Wits Healths Systems Trust, p. 35.

World Health Organisation 1982: The role of nursing in the primary health care team. Geneva: World Health Organisation.

World Health Organisation 1985: Health for all by the year 2000. Euro Reports \& Studies. WHO: Regional Office. 